\title{
TRIBAL PLANTS AND THEIR INBORN ANTIMICROBIAL ACTIVITIES
}

\section{ANITHA JEGADEESHWARI L, DHARATHI N, VIDHYA LAKSHMI D, VASANTH KUMAR E, NAGENDRA GANDHI N*}

Department of Chemical Engineering, ACT Campus, Anna University, Chennai - 600 025, Tamil Nadu, India.

Email: nagendragandhi.n@gmail.com

Received: 13 March 2017, Revised and Accepted: 14 April 2017

ABSTRACT

The importance of medicinal plants in traditional health-care practices provides clues to new areas of research and in the biodiversity of conservation. Right from the beginning, the documentation of traditional knowledge, especially on the medicinal uses of plants, has provided many important drugs for the modern day. Even today, this area holds much more hidden treasure as almost $80 \%$ of the human population in developing countries depend on plant resources for health care. Keeping this in view, the present study was initiated to document the traditionally used tribal plants and their inborn antimicrobial activity which is enhanced on the synthesis of noble metal nanoparticles.

Keywords: Nanoparticles, Tribal plants, Antimicrobial activity.

(c) 2017 The Authors. Published by Innovare Academic Sciences Pvt Ltd. This is an open access article under the CC BY license (http://creativecommons. org/licenses/by/4. 0/) DOI: http://dx.doi.org/10.22159/ajpcr.2017.v10i7.18439

\section{INTRODUCTION}

About 5000 years ago, several countries used silver to store food products. Greeks and Romans stored water in silver vessels. In the 1800s, silver was used in various application fields such as drinking, storing the food products, and cosmetics. It was even used in the treatment of ulcer. In the 1880s, silver nitrate drops were used as antibiotic drops for newborn babies [1]. In the 1920s, silver was used to manage wounds. Silver ions have the capacity to act against microbes. This is one of the major reasons why the royals used silver utensils. In the Hindu religion, till date, silver utensils are preferred for the "panchamrita" preparation using curd, Ocimum sanctum, and other ingredients [2].

Combining the ever significant silver with the flourishing nanotechnology has given tremendous results in the field of tissue engineering, drug delivery, food industries, and pharmaceutical industries. Among various metals, silver nanoparticles (AgNPs) are of particular interest due to their noteworthy antimicrobial and their localized surface plasmon properties which renders them in having broad-spectrum in antimicrobial [3,4] activity, surface enhanced Raman spectroscopy [5], chemical/biological sensors and Biopharma materials [6,7], biomarker [8-9], and so on

AgNPs are ranged from 1 to $100 \mathrm{~nm}$ in size naturally. They have exceptional optical, thermal, and electrical properties. They are incorporated into industrial applications. Recent trend demands for the thick-printed, electronic circuits due to the space between these circuits [12-14]. Therefore, the synthesis of AgNPs becomes an important issue in this industry. The synthesis of noble metal nanoparticles can be carried out by three major methods which are physical, chemical, and biological methods. AgNps have been synthesized by physiochemical techniques such as chemical reduction [14], gamma ray radiation [15], microemulsion [16], electrochemical method [17], laser ablation [18], autoclave [19], microwave [20], and photochemical reduction [21]. The effective yield method is associated with the limitations such as use of toxic chemicals, higher operational cost, and energy needs. Considering the drawbacks of physiochemical methods, cost-effective and energy efficient new alternative for AgNP synthesis using microorganisms [22], plant extracts [23], and natural polymers [24] as reducing and capping agents are emerging very fast [25].

Traditional herbal medicines (THMs) in the last one decade have gained importance in various developed countries. THM is practiced in several parts of the world, especially in Africa, Bangladesh, China, Europe, West side of America, Russia, Pacific Islands where large ethnic community still lives on. History has revealed that most of the people in the world have been using plants, animals, microorganisms, and minerals in treating their illness [26]. One-third of the adults from America, 74\% population of the United Kingdom, and about $60 \%$ of population from the Netherlands and Belgium are now utilizing alternative herbal therapies (WHO, 1996).

India is blessed with a rich and diverse heritage of cultural traditions. These traditions are associated with the usage of wild plants as medicinal herbs. The use of medicinal herbs is still a tradition adopted by ethnic communities who are living in undulating plains and at the foothills of dense forest. Shanker (1998) has reported about traditional folk healers in India [27].

The Central part of India comprises states such as Chhattisgarh, Maharashtra, Odisha, Jharkhand, and Madhya Pradesh. The people of this region are ethnically called as Bhil, Gond, Hill Korwa, Baiga, Bhariya, Birhor, and Sahariyas. They use a wide range of wild tribal plants for their health care. Green synthesis of AgNPs using tribal plants, such as Lawsonia inermis, Vitex negundo, Artemisia nilagirica, Crataegus douglasii, Ziziphus mauritiana, Mucuna pruriens, Coleus amboinicus, and Datura metel can result in biologically and cytologically compatible metallic nanoparticles [28]

\section{TRIBAL PLANTS}

\section{Coleus amboinicus Lour}

Botanical name: Labiatae

Family: Lamiaceae

Species: C. amboinicus

C. amboinicus Lour, it is under the kingdom - Plantae, family - Lamiaceae, and the species is amboinicus. The leaves are thick and have a length of $1-2^{\prime \prime}[29]$. It is a small plant with a stem height of $1-2 \mathrm{ft}$. It has some hairs on it. Flowers are blue and purple in color.

It flowers in early summers. For its essential oil, it has been cultivated in the Far East. Before the end of the $19^{\text {th }}$ century, the plant was scattered in Caribbean and from northern Venezuela to Yucatan. This plant contains monoterpenoid, luteolin, and flavonoids. It has been used in the treatment of cough, chronic asthma, fever, and bronchitis [30]. 
The parts of the plant were used for medicinal purposes, such as juice for indigestion, cholera, gastrointestinal, and diarrhea. The leaves of C. amboinicus contain phenolic compounds such as carvacrol, flavonoid, rosmarinic, caffeic acid, and chlorogenic acid. Powdered leaf is used for aches, paralysis, cough, cold, and asthma, and in best condition, it is applied to insect bites and headaches [31]. The flavonoid contents of this plant include Flavonoid: salvigenin, 6-methoxygenkwanin, quercetin, chrysoeriol, luteolin, apigenin, Flavanoid: eriodictyo, and flavanol taxifolin, thus making it efficient against Pseudomonas aeruginosa, Bacillus subtilis, Escherichia coli, Staphylococcus aureus, Trichophyton mentagrophytes, and Aspergillus niger [32]. Essential oil of this plant is effective against fungi and bacteria while hydroalcoholic extract of this plant is active against methicillin-resistant $S$. aureus [33].

\section{Datura metel}

Botanical name: Datura stramonium

Family: Solanaceae

Species: D. metel

D. metel is a shrub-like perennial herb plant and is called as devils trumpet [34]. The common name for this plant is thorn apple and the Tamil name is Ummattangani/Vella-Ummathai [35]. The plant can grow up to $3 \mathrm{ft}$. It has dark violet shoots and oval leaves. The colors are yellow, red, and cream. The seeds are numerous with conical humps and a few spines [36]. The biomolecules present in the plant are scopolamine, vitamin, hyoscine, fastusic acid, etc. It has been used mainly in pharmaceutical industries for ointment, hair growth, asthma, cough, etc [37].

It has a wide range of applications in India, including in the treatment of many diseases such as epilepsy and few mental health issues such as hysteria and insanity. It has also been used for heart diseases, fever with catarrh, diarrhea, skin diseases, etc [39]. In China, the plant is used in the treatment of asthma [40]. In Vietnam, the dried flowers and leaves are cut into small chips and are used in antiasthmatic cigarettes [41]. The whole plant, especially the leaves and seed, has significant properties for anesthetic. It can also be used for anodyne, antiasthmatic, antispasmodic, and antitussive. It has also been used for bronchodilator, hallucinogenic, hypnotic, and mydriatic [38].

Great caution is advised on the usage of this plant since excess doses cause hallucinations. It even leads to death on severe intoxication. This plant should only be used under the guidance of a qualified practitioner as its toxic dose is very close to medicinal does [42]. The plant contains the alkaloids such as hyoscyamine, hyoscine, and atropine. Atropine dilates the pupils. It is also used in eye surgery [43]. The total alkaloid content of the leaves is $0.426 \%$, which is mainly atropine. The seeds contain $0.426 \%$ alkaloids, which is mainly hyoscyamine. The roots contain $0.35 \%$ hyoscyamine. An extract of $3 \mathrm{~g}$ of the flowers is used as an anesthetic which can last up to 5-6 hrs [44]. The growing datura plant acts as an insect repellent. The juice of datura plant is applied over the scalp to treat hair fall, hair loss, and dandruff [45]. The presence of alkaloids such as scopolamine, hyoscyamine, and atropine makes datura poisonous [46].

\section{Artemisia nilagirica \\ Botanical name: Artemisia nilagirica \\ Family: Asteraceae}

It is a tribal plant which is widely present in India. It is mostly found throughout the hilly regions such as Kashi, Sikkim, Kerala, and other places [47]. The parts of this plant can be used for many applications. Oil possesses antifungal, antimicrobial, insecticidal, and larvicidal activity since it contains compounds such as camphor, 1,8-cineole, eudesmol, artemisia alcohol, gurjunene, para-cymene, terpinene-4-ol, and pinene [48]. The oil from the seed is used for effectiveness of skin and to kill the head lice. The seed extract is used to treat heart failures and it is one of the best drugs in pharmaceutical industries [49]. The bark is used externally for all skin troubles, and it is used to treat diarrhea, piles, and urinary problems. The fresh juice of bark is good to treat diarrhea [50].

Conventionally, it is used in the management of epilepsy, nervous disorders, as diuretic, anti-inflammatory, and skin disorders [51], but recently, it was found to possess pharmaceutical properties. These evidences prove that the whole plant is of great therapeutic valve.

The future prospect includes preclinical studies on the aerial parts as well as root [34]. Extracts of A. nilagirica showed the broad spectrum of antibacterial activity on the tested microorganisms. Hexane extract exhibited high inhibitory potency against phytopathogens and methanol extract showed maximum inhibition against clinical pathogens except S. aureus, Enterococcus faecalis, and Klebsiella pneumonia [52]. The phytochemical analysis showed the presence of effective biological compounds such as alkaloids, amino acids, flavonoids, phenols, tannins, and terpenoids. These derivatives could be potential alternatives to the traditional chemical control of clinical pathogen and phytopathogenic bacteria as shown in Table 1 [53].

\section{Lawsonia inermis}

Botanical name: Lawsonia inermis

Family: Lythraceae

Species: L. inermis

L. inermis is a tribal plant, which is widely present in India. This species is globally distributed in the Paleotropics [54]. It is cultivated within India for its leaves throughout and as a hedge-plant in Punjab and Gujarat. To a small extent, it is cultivated in Madhya Pradesh and Rajasthan [55]. Important centers of production include Faridabad (Punjab), Bardoli, and Madhi (Gujarat) [56].

The common name of this plant is Henna. L. inermis is a small shrub plant which has bioactive compounds such as lawsone, fraxetin, gallic acid, coumarins, resins, and tannin. Among these compounds is the major ingredient which gives its characteristic color [57]. This plant has been used in pharmaceutical industries since ancient times. The leaves are used to treat as lumbago, diarrhea, bronchitis, wounds, rheumatalgia, fever, and falling of hair [58].

The phytochemical compounds present in the juice are 1,4-naphthoquinone, 2-hydroxy-1,4-naphthoquinone, $\beta$-sitosterol, esculetin, cosmosiin, laloiside, quinone, scopoletin, tilianin. These compounds help in the treatment of diabetes, skin diseases, hemorrhage, and fungal infections [59].

In Western and the Middle East, henna is used in hair dyes, shampoo, and conditioners [60]. Extracts of henna are also used to stain wood and to dye fabric and textiles. It is also known as good medicinal plant which has properties of astringent, antihemorrhagic, intestinal antineoplastic and sedative effects [61].

Henna extracts have antibacterial and antifungal properties while the aromatic flowers are used for making of perfumes [62]. Conventionally, henna is used to create beautiful designs on hands and other body parts of body on various occasions such as weddings and festivals. Applying henna on the wedding and festivals is considered auspicious [63].

\section{Vitex negundo}

Botanical name: Vitex negundo Linn.

Family: Verbenaceae (Nirgundi Kula)

Species: V. negundo

V. negundo Linn. (Verbenaceae) is a woody, aromatic shrub growing to a small tree. It grows in humid places or along water courses in wastelands and also in mixed open forests [64]. It has been reported to occur in Afghanistan, India, Pakistan, Sri Lanka, Thailand, Malaysia, Eastern Africa, and Madagascar. It is grown commercially as a crop in parts of Asia, Europe, North America, and the West Indies [65]. 
Table 1: Efficacy of AgNPs when synthesized using the essential parts of tribal plants

\begin{tabular}{|c|c|c|c|c|c|c|c|}
\hline S. No. & $\begin{array}{l}\text { Name of } \\
\text { the plant }\end{array}$ & $\begin{array}{l}\text { Parts } \\
\text { used }\end{array}$ & Authors & $\begin{array}{l}\text { Operating } \\
\text { conditions }\end{array}$ & Characterization & Size & Inference \\
\hline 1 & $\begin{array}{l}\text { Coleus } \\
\text { amboincious } \\
\text { lour }\end{array}$ & Leaves & Vadivel et al. & $\begin{array}{l}1 \mathrm{mM}, 50 \mathrm{ml} / 50 \mathrm{ml} \\
80,1 \mathrm{hr}\end{array}$ & $\begin{array}{l}\text { UV-Vis, FTIR, } \\
\text { EDAX }\end{array}$ & $25.83-0.78 \mathrm{~nm}(\mathrm{fcc})$ & $\begin{array}{l}\text { FRAP reduction by extract is } \\
350 \mu \text { moles } / \mathrm{mg}\end{array}$ \\
\hline 2 & $\begin{array}{l}\text { Datura } \\
\text { metel }\end{array}$ & Leaves & $\begin{array}{l}\text { Murugan } \\
\text { et al. }\end{array}$ & $\begin{array}{l}1 \mathrm{mM}, 10 \mathrm{ml} / 90 \mathrm{ml} \\
30,10 \text { minute }\end{array}$ & $\begin{array}{l}\text { UV-Vis, FTIR, } \\
\text { EDAX }\end{array}$ & $\begin{array}{l}\text { Irregular shapes and } \\
\text { size of } 40-60 \mathrm{~nm}\end{array}$ & $\begin{array}{l}\text { Showed efficient results against } \\
\text { larvae of Anopheles stephensi }\end{array}$ \\
\hline 3 & $\begin{array}{l}\text { Artemisia } \\
\text { uilagirican }\end{array}$ & Leaves & Mittal et al. & $\begin{array}{l}1 \mathrm{mM}, 10 \mathrm{ml} / 90 \mathrm{ml} \text {, } \\
30,45 \text { minute }\end{array}$ & $\begin{array}{l}\text { UV-Vis, FTIR, } \\
\text { SEM, XRD }\end{array}$ & $\begin{array}{l}50-350 \mathrm{~nm} ; \\
\text { spherical, triangular }\end{array}$ & $\begin{array}{l}\text { Antimicrobial activity against } \\
\text { Escherichia coli and Vibrio } \\
\text { cholera }\end{array}$ \\
\hline 4 & $\begin{array}{l}\text { Lawsonia } \\
\text { inermis }\end{array}$ & Leaves & Kumar et al. & $\begin{array}{l}1 \mathrm{mM}, 10 \mathrm{ml} / 90 \mathrm{ml} \text {, } \\
80,25 \text { minute }\end{array}$ & $\begin{array}{l}\text { UV-Vis, SEM, } \\
\text { EDAX, XRD, ZETA } \\
\text { potential }\end{array}$ & $\begin{array}{l}13-61 \mathrm{~nm} \text {, } \\
\text { conductivity value is } \\
\text { about } 0.439 \mathrm{mS} / \mathrm{cm} \text {, } \\
\text { spherical, fcc }\end{array}$ & $\begin{array}{l}\text { Antibacterial activity against } \\
\text { beta-haemolytic Streptococcus } \\
\text { sp., Bacillus sp. }\end{array}$ \\
\hline 5 & $\begin{array}{l}\text { Vitex } \\
\text { negundo }\end{array}$ & Leaves & $\begin{array}{l}\text { Kathireswar } \\
\text { et al. }\end{array}$ & $\begin{array}{l}1 \mathrm{mM}, 10 \mathrm{ml} / 90 \mathrm{ml} \text {, } \\
80,15 \text { minute }\end{array}$ & $\begin{array}{l}\text { UV-Vis, FTIR, } \\
\text { SEM, XRD }\end{array}$ & $60 \mathrm{~nm}$, spherical, fcc & $\begin{array}{l}\text { Antimicrobial action } \\
\text { against Escherichia coli, } \\
\text { Staphylococcus aureus, } \\
\text { Pseudomonous sp., Proteus } \\
\text { vulgaris, and Salmonella typhi. }\end{array}$ \\
\hline 6 & $\begin{array}{l}\text { Zizyphus } \\
\text { mauritiana }\end{array}$ & Leaves & $\begin{array}{l}\text { Sadeghi } \\
\text { et al. }\end{array}$ & $\begin{array}{l}1 \mathrm{mM}, 10 \mathrm{ml} / 90 \mathrm{ml} \text {, } \\
30,20 \text { minute }\end{array}$ & $\begin{array}{l}\text { UV-Vis, FTIR, } \\
\text { SEM, XRD }\end{array}$ & $\begin{array}{l}15-35 \mathrm{~nm}, \mathrm{fcc} \\
\text { spherical }\end{array}$ & $\begin{array}{l}\text { Antibacterial } \\
\text { Action against } \\
\text { Gram-positive } \\
\text { (Staphylococcus aureus) }\end{array}$ \\
\hline 7 & $\begin{array}{l}\text { Mucuna } \\
\text { pruriens }\end{array}$ & Seed & $\begin{array}{l}\text { Arul Kumar } \\
\text { et al. }\end{array}$ & $\begin{array}{l}1 \mathrm{mM}, 10 \mathrm{ml} / 90 \mathrm{ml} \text {, } \\
30,1 \mathrm{hr}\end{array}$ & $\begin{array}{l}\text { UV-Vis, FTIR, } \\
\text { TEM, XRD }\end{array}$ & $\begin{array}{l}\text { 10-27 nm, oval, } \\
\text { spherical, triangle, } \\
\text { and circular. fcc } \\
\text { structure }\end{array}$ & $\begin{array}{l}\text { AgNps is used for biomedical } \\
\text { and pharmaceutical } \\
\text { applications }\end{array}$ \\
\hline
\end{tabular}

FTIR: Fourier transforms infrared, EDAX: Energy dispersive X-ray, UV-Vis: Ultraviolet-visible, SEM: Scanning electron microscopy, XRD: X-ray diffractometry, AgNPs: Silver nanoparticles, fcc: Face-centered cubic, FRAP: Ferric reducing antioxidant power, TEM: Transmission electron microscopy

V. negundo also finds use as a food crop (Facciola, 1990) and as a source of timber. Vitex plant grows up to $10 \mathrm{ft}$. The origin of the plant is India and is easily cultivated cause of its eco-friendly nature. It is costeffective. It commonly bears tri- or penta-foliate leaves on quadrangular branches, which gives rise to bluish-purple colored flowers in branched tomentose cymes [66].

In the USA, purple flowers bloom during summer which is popularly visited bees and butterflies.

The juice from leaves contains casticin, isoorientin, chrysophanol D, luteolin, p-hydroxybenzoic acid, and D-fructose [67] while the main constituents of the oil are sabinene, linalool, terpinen-4-ol, $\beta$-caryophyllene, $\alpha$-guaiene, and globulol, which constitutes $61.8 \%$ of the oil. In vitro and animal studies have shown that chemicals isolated from the plant have potential anti-inflammatory, antibacterial, and antifungal activities [68].

V. negundo is also used for treating stored garlic against pests and as a cough remedy in the Philippines [69] while the roots and leaves are used in eczema, ringworm and other skin diseases such as liver disorders, spleen enlargement, rheumatic pain, gout, abscess, and backache. Seeds are used as vermicide. It is also used to control population of mosquitoes [70]. Herbal medicine, rather than merely curing a particular disease, aims at returning the body back to its natural state of health [71]. The phytochemical components of plants act either individually, collectively, or synergistically for the improvement of health [72].

After analyzing the different chemical components present in the plant, it is important that focus shifts to the medicinal applications of the plant. Myriad medicinal properties have been found in the plant and the plant has also been extensively used in treatment of a plethora of ailments [73]. These properties have been classified under three categories - traditional medicine, folk medicine, and pharmacological evidence.
Traditional medicine practices that mainly followed are Indian Ayurvedic, Arabian Unani medicine, and Chinese medicine. The historical and cultural beliefs have made the population of Asia and Latin America to continue the use of traditional medicine [74]. Traditional medicine accounts for around $40 \%$ of all health care delivered in China. Up to $80 \%$ of the population in Africa uses traditional medicine to help meet their health care needs [75].

In Ayurveda, the plant finds its mention in the verses of the "Charaka Samhita" the most unarguable and authoritative textbook of Indian Ayurvedic medicine. V. negundo has been designated as an anthelminthic (verse Su: 4-15) and is prescribed as a vermifuge (verse Vi: 7-21) in the exposition on the Charaka Samhita by Sharma [76]. Other Ayurvedic uses of $V$. negundo are described by Tirtha [77]. People sleep on pillows stuffed with $V$. negundo leaves to dispel catarrh and headache and smoke the leaves for relief. Crushed leaf is applied to cure headaches and other skin wounds [78]. Essential oil obtained from the leaves is effective in the treatment of venereal and other skin diseases. The leaf decoction along with piper nigrum is used to treat catarrhal fever with heaviness of head and dull hearing [79].

Tincture of root bark provides relief from bladder irritation and rheumatism. Jadhav and Bhutani [80] reported the Ayurvedic use of $V$. negundo in dysmenorrhea. Patkar [81] refers the formulations mentioned in the book of Anubhoga Vaidya Bhaga, which is a compendium of formulations in cosmetology, which outlines the usage of $V$. negundo leaves along with Azadirachta indica, Eclipta alba, Sphaeranthus indicus, or Carum copticum in a rejuvenation treatment process known as Kayakalpa. In Unani medicine, Khare [82] outlines the applications of $V$. negundo, commonly known as Nisinda in Unani medicine. The seeds are administered internally with sugar cane vinegar for removal of swellings; it is also used in spermatorrhoea and serves as an aphrodisiac when dispensed along with dry Zingiber officinale and milk [83].

In Chinese medicine, Pharmacopoeia prescribes the fruit of $V$. negundo in the treatment of reddened, painful, and puffy eyes; headache; and 
arthritic joints [84]. The Folklore systems of medicine serve a large segment of population even today, especially in rural and tribal areas, regardless to the advancement in modern medicine [85].

\section{Ziziphus mauritiana}

Botanical names: Ziziphus mauritiana Lamk

Family: Rhamnaceae

Species: Z. mauritiana

Z. mauritiana is a rapidly growing medium-sized tree with a rapidly developing taproot, a necessary adaptation for drought conditions [86]. The species vary widely in height, from a bushy shrub $1.5-2 \mathrm{~m}$ tall, to a tree of 10-12 m tall with a trunk diameter of $30 \mathrm{~cm}$.

Z. mauritiana belongs to the species of the genus Ziziphus tourn. ex L. family rhamnaceae. The name Ziziphus is related to an Arabic word which is used along the North African coast area. Zizoufo is used for Ziziphus lotus (L.)Desf., but it is also related to the ancient Persian words zizfum or zizafun. The ancient Greeks used the word ziziphon for the jujube [90].

Z. mauritiana may erect or wide-spreading. It has drooping thorny branches with zigzag branchlets and a thornless or with a set of short, sharp straight or hooked spines [87]. The fruit can be eaten raw or pickled. It is used in beverages because it has vitamin C. It is second only to guava and much higher than citrus or apples [88].

In India, the ripe fruits are mostly consumed raw but are sometimes stewed. The chemical composition is rich in vitamin $C$ plus, it contains Jujubosides A\&B (seeds) with zizogenin, and zeatin. It also has frangufoline, saponin, etc. The seeds have found to have compositions such as betulinic aldehyde and acids such as betulinic acid and ceanothic acid. It also contains frangufoline, spinosin, beta-sitosterol, daucosterol, daucosterol-6'-octadecanoate, sucrose, docosanoic acid, stearic acid, and palmitoleic acid [89].

During $1500 \mathrm{BC}$, Jujubes were eaten by the ancients of the chalcolithic age. The fruits have been cultivated for the past 400 years in both India and China. These fruits have been quite frequently mentioned in Veda, such as the Sutras, epics, medical texts, and other literature [91]

Three types of jujubes are mentioned in Veda and Brahmanas. They are Badara with large-sized fruit, the Koal or Ktmila with average sized fruit, and Karkandhu with orange-reddish fruit; whereas, the first two types appear to be Z. mauritiana, and the third type, with its red fruit, appears to be Ziziphus nummularia [92].

Z. mauritiana is extremely drought hardy and is dominant component of the natural vegetation in the Indian "Thar desert." It can be successfully cultivated even in the most marginal ecosystem of the tropics and subtropics. 90,000 ha plantation of improved bare trees has made in India, which have average productivity of 8.34 tons per hectare [93].

However, all jujubes remain relatively minor crops, although demand for production remains steady in various parts of world, especially India where they were originally domesticated [94]. Z. mauritiana is considered as an underutilized crop and is included in national program on underutilized crops. In spite of the fact that Z. mauritiana has tremendous medicinal properties, attributed by a diverse group of secondary metabolites it is neither considered as an important medicinal plant nor as a utility for medicinal use in mainstream therapeutics [95].

Thus, this paper provides a dignified review of information regarding the ethnopharmacological uses, pharmacological activity, and phytochemical constituents of the plant Z. mauritiana, with the purpose of drawing scientific focus of this underutilized medicinal plant, for strategic planning to optimize judicious, sustainable use, and long-lasting conservation. The fruits are a good source of vitamin
$\mathrm{C}$ and sugars. It contains appreciable amounts of mineral constituents. A typical analysis of the pulp shows $82 \%$ moisture, 0.8 protein, and 0.3 fat, carbohydrates, 17.0; and minerals, $0.3 \%$; calcium, 4; phosphorus, 9; iron, 1.8; carotene, 0.021; thiamine, 0.02; riboflavin, 0.02; niacin, 0.7; and vitamin C, $76 \mathrm{mg} / 100 \mathrm{~g}$. The presence of fluoride $(0.1-0.2 \mathrm{ppm})$ is reported; pectin content (as calcium pectate) is $2.2-3.4 \%$, on moisturefree basis [96].

Fresh fruits contain quercetin. The total lipid content of jujube fruit is very low. The predominant fatty acids in jujube are oleic acid, linoleic acid, palmitic acid, and palmitoleic acid. Palmitic acid is the main saturated fatty acid while unsaturated fatty acids range from $68.54 \%$ to $72.44 \%$ of the total fat present in jujube fruit. Therefore, jujube fruits can be recommended by nutritionists to be part of our daily diet [97].

Z. mauritiana varieties include Gola, Umran, Thar Bhubhraj, Thar Sevika, Banarasi Karaka, Illaichi, Seb, Ponda Tikadi, Katha, Bawal-Sel-1, Sanaur-2 etc. From top to root, Z. mauritiana is useful, as food, fodder, nutrient, medicine, construction material or as fuel.

As per ayurveda and ethnomedicinal claims, Z. mauritiana has tremendous medicinal properties, attributed by alkaloids. Although in-depth phytochemical investigation of $Z$. mauritiana has been carried out, each phytoconstituent has unique and multifactorial properties [98]. Undisputed value of $Z$. mauritiana is seen in health products and their wide geographical range means they can provide a potentially cheaper and more accessible source of such compounds for traditional medicine [99].

\section{Mucuna pruriens}

Botanical name: Mucuna pruriens L.

Family: Fabaceae

Species: M. pruriens

The plant is an annual climbing shrub with long vines that can reach over $15 \mathrm{~m}$ (50 ft) length. Young plants are covered by fuzzy hairs, but when older, it is almost completely free of hairs [100]. The leaves are tripinnate, ovate, reverse ovate, rhombus-shaped, or widely ovate.

Mucuna spp. Have been reported to contain the toxic compounds L-dopa and hallucinogenic tryptamines, and anti-nutritional factors, such as phenols and tannins (Awang et al., 1997). Higher concentrations of L-dopa with velvet bean is a commercial source of this substance. It is used in the treatment of Parkinson's disease [101]. Unprocessed velvet bean exhibits a low susceptibility to insect pests (Duke, 1981). Velvet bean is known for its nematicidic effects. It is also possesses allelopathic activity (Gliessman et al., 1981).

Despite its harzardous properties, various species of Mucuna are grown as a minor food crop because raw velvet bean seeds contain approximately $27 \%$ protein (Duke, 1981). During the $18^{\text {th }}$ and $19^{\text {th }}$ centuries in the foothills and lower hills of the eastern Himalayas and in Mauritius, Mucuna was grown widely as a green vegetable. Both the green pods and the mature beans were boiled for eating purposes. The seeds of $M$. pruriens have been used for treating many dysfunctions in Unani Medicine. In Guatemala and Mexico, M. pruriens has been roasted and grounded to make a coffee substitute; the seeds are widely known in the region as "Nescafé," in recognition of this use [102].

The plant and its extracts have been long used for various snake bites. M. pruriens has compounds such as levodopa and L-dopa. This is a proactive chemical precursor and has significant antioxidant. This helps in the action that works in tandem with L-dopa to promote brain health. When L-dopa crosses the blood-brain barrier, it helps increase brain levels of dopamine. It is an essential neurotransmitter associated with regulating mood and cognition [103]. It has also been studied for its effects against various snake bites such as cobra, Echis (Saw scaled viper), Calloselasma (Malayan pit viper), and Bungarus (Krait). 
It has long been used in traditional Indian medicine, i.e. Ayurveda in an attempt to treat various diseases including Parkinson's disease. The phytochemicals of the seeds of the plant contain serotonin, nicotine, and bufotenine. Thus, it has been used in Siddha system of medicine for various purposes [104].

\section{CONCLUSIONS}

The need of time is to perform the pharmacological activities of isolated phytochemical, which can replace synthetic and costly medicine and attract the interest from large pharmaceutical companies. This paper provides review of information regarding ethno pharmacological uses, pharmacological activity, and phytochemical constituents of C. amboinicus Lour, D. metel, A. nilagirica, L. inermis, V. Negundo, $Z$. mauritiana, $M$. pruriens with the purpose of drawing scientific focus toward these underutilized medicinal plants. Thus, the present documentation of traditional knowledge will not only provide recognition of this knowledge but also help in its conservation through providing pharmacological leads for the betterment of human society.

\section{REFERENCES}

1. Kumar GP, Chikkappaiah L, Nagayya S. Nutritional analysis of edible wild plants used by Hakki Pikki tribes of Hassan district, Karnataka, India. Int J Pharm Pharm Sci 2016;8(8):975-1491.

2. Pooja S, Vidyasagar GM. Ethnomedicinal plants used by rajgond tribes of Haladkeri village in Bidar district, Karnataka, India. Int J Pharm Pharm Sci2015;8(7):975-1491.

3. Manikandan D, Jegadeeshwari LA, Gandhi NN. Biological activity sources from traditionally used tribe and herbal plants material. Asian J Pharm Clin Res 2015;8(16):11-23

4. Vadivel S. Green synthesis of silver nanoparticles using Coleus amboinicus lour, antioxidant activity and in vitro cytotoxicity against Ehrlich's ascite carcinoma. J Pharm Res 2012;5(2):1268-72.

5. Lacey LA, Orr BK. The role of biological control of mosquitoes in integrated vector control. Am J Trop Med Hyg 1994;50 6 Suppl:97-115.

6. Israel LL, Lellouche E, Grenèche JM, Bechor M, Michaeli S, Lellouche JP, et al. Ultrasound-mediated surface engineering of theranostic magnetic nanoparticles: An effective onepot functionalization process using mixed polymers for SiRNA delivery. J Nanomed Nanotechnol 2016;7:385..

7. Liu H, Xu Q, Zhang L, Liu N. Chlorpyrifos resistance in mosquito Culex quinquefasciatus. J Med Entomol 2005;42(5):815-20.

8. Medlock JM, Snow KR Natural predators and parasites of British mosquitoes - A review. Eur Mosq Bull 2013;25:1-11.

9. Mehlhorn H, editor. Nature Helps. How Plants and Other Organisms Contribute to Solve Health Problems. New York: Parasitology Research Monographs; 2007. p. 1-372.

10. Mehlhorn H, Schmahl G, Schmidt J. Extract of the seeds of the plant Vitex agnus castus proven to be highly efficacious as a repellent against ticks, fleas, mosquitoes and biting flies. Parasitol Res 2005;95(5):363-5.

11. Mehlhorn H, Al-Rasheid KA, Al-Quraishy S, Abdel-Ghaffar F. Research and increase of expertise in arachno-entomology are urgently needed. Parasitol Res 2012;110(1):259-65.

12. Morones JR, Elechiguerra JL, Camacho A, Holt K, Kouri JB, Ramírez JT, et al. The bactericidal effect of silver nanoparticles. Nanotechnology 2005;16(10):2346-53.

13. Murugan K, Dinesh D, Kumar PJ, Panneerselvam C, Subramaniam J, Madhiyazhagan P, et al. Datura metel-synthesized silver nanoparticles magnify predation of dragonfly nymphs against the malaria vector Anopheles stephensi. Parasitol Res 2015;114:4645-54.

14. Gan PP, Li SF. Potential of the plant as a biological factory to synthesize gold and silver nanoparticles and their applications. Rev Environ Sci Biotechnol 2012;11:169-206.

15. Gardea-Torresdey JL, Gomez E, Peralta-Videa JR, Parsons JG, Troiani H, Jose-Yacaman M. Alfalfa sprouts: A natural source for the synthesis of silver nanoparticles. Langmuir 2003;19:1357-61.

16. Gericke M, Pinches A. Biological synthesis of metal nanoparticles. Hydrometallurgy 2003; 83:132-40.

17. Ghodake GS, Deshpande NG, Lee YP, Jin ES. Pear fruit extractassisted room-temperature biosynthesis of gold nanoplates. Colloids Surf B Biointerfaces 2010;75:584-9.

18. Ghosh S, Patil S, Ahire M, Kitture R, Kale S, Pardesi K, et al. Synthesis of silver nanoparticles using Dioscorea bulbifera tuber extract and evaluation of its synergistic potential in combination with antimicrobial agents. Int J Nanomedicine 2012;7:483-96.

19. Akhtar MS, Qureshi AQ, Iqbal J. Antidiabetic evaluation of Mucuna pruriens Linn seeds. JPMA 1990;40:147-50.

20. Min KM, Khan MN, Zillur-Rehman S, Khan NA. Sexual function improving effect of Mucuna pruriens in sexually normal male rats. Fitoterapia Milano 1996;67:53-6.

21. Awang D, Buckles D, Arnason JT. Paper Presented at the International Workshop on Green Manure - Cover Crop Systems for Smallholders in Tropical and Subtropical Regions 6-12 April, Rural Extension and Agricultural Research Institute of Santa Catarina, The Phytochemistry, Toxicology and Processing Potential of the Covercrop Velvetbean (cow (h)age, cowitch) (Mucuna adans. spp, Fabaceae). Chapeco, Catarina, Brazil, Santa Catarina; 1997.

22. Divya L, Vijay KM. Preparation and applications of chitosan nanoparticles: A brief review. Mater Sci 2016;

23. Sougata G, Gurav SP, Harke AN, Chacko MJ, Sonal P. Gloriosa superba mediated synthesis of silver and gold nanoparticles for anticancer applications. J Nanomed Nanotechnol 2016;7:390.

24. Rajesh A. Applications of upconversion nanoparticles in nanomedicine. J Nanomed Nanotechnol 2016;7:e141.

25. Briganti S, Picardo M. Antioxidant activity, lipid peroxidation and skin diseases. What's new. J Eur Acad Dermatol Venereol 2003;17:663-9.

26. Chaudhri RD. Herbal Drug Industry: A Practical Approach to Industria. New Delhi: Eastern Publishers; 1996. p. 537-46.

27. Di Patrizi L, Rosati F, Guerranti R, Pagani R, Gerwig GJ, Kamerling JP. Structural characterization of the N-glycans of gpMuc from Mucuna pruriens seeds. Glycoconj J 2006;23(7-8):599-609.

28. D'Mello JP. Anti-nutritional substances in legume seeds. In: D'Mello JP, Devendra C, editors. Tropical Legumes in Animal Nutrition. Wallingford, UK: Cab International; 1995. p. 135-72.

29. Fornoni J, Núñez-Farfán J. Evolutionary ecology of Datura stramonium: Genetic variation and costs for tolerance to defoliation. Evolution 2000;54:789-97.

30. Luna-Cavazos M, Bye R. Phytogeographic analysis of the genus Datura (Solanaceae) in continental Mexico. Rev Mex Biodivers 2011;82:977-88.

31. Berkov S, Zayed R, Doncheva T. Alkaloid patterns in some varieties of Datura stramonium. Fitoterapia 2006;77:179-82.

32. Ajungla L, Patil PP, Barmukh RB, Nikam TD. Influence of biotic and abiotic elicitors on accumulation of hyoscyamine and scopolamine in root cultures of Datura metel L. Indian J Biotechnol 2009;8(3):317-22.

33. Dessanges JF. A history of nebulization. J Aerosol Med 2001;14:65-71.

34. Diker D, Markovitz D, Rothman M, Sendovski U. Coma as a presenting sign of Datura stramonium seed tea poisoning. Eur J Intern Med 2007; 18:336-8

35. Naudé TW, Gerber R, Smith RJ, Botha CJ. Datura contamination of hay as the suspected cause of an extensive outbreak of impaction colic in horses. J S Afr Vet Assoc 2005;76:107-12.

36. Norton S. Toxic effects of plants. In: Klaassen CD, editor. Caserett and Doull's Toxicology, The Basic Science of Poisons. $7^{\text {th }}$ ed. New York: McGraw Hill; 2008 . p. 1110.

37. Kirtikar KR, Basu BD. Indian Medicinal Plants. $2^{\text {nd }}$ ed., Vol. III. Dehradun: International Book Distributors; 1999. p. 1783-7.

38. Donati D, Lampariello LR, Pagani R, Guerranti R, Cinci G, Marinello E. Antidiabetic oligocyclitols in seeds of Mucuna pruriens. Phytother Res 2005; 19:1057-60.

39. Diker D, Markovitz D, Rothman M, Sendovski U. Coma as a presenting sign of Datura stramonium seed tea poisoning. Eur J Int Med 2007;18(4):336-8

40. Swathi S, Murugananthan G, Ghosh SK, Pradeep AS. Larvicidal and repellent activities of ethanolic extract of Datura stramonium leaves against mosquitoes. Int J Pharm Phytochem Res 2012;4(1):25-7.

41. Gupta S, Raghuvanshi M, Jain D. Comparative studies on antiinflammatory activity of Coriandrum Sativum, Datura stramonium and Azadirachta Indica. Asian J Exp Biol Sci 2010;1(1):151-4.

42. Guerranti R, Aguiyi JC, Neri S, Leoncini R, Pagani R, Marinello E. Proteins from Mucuna pruriens and enzymes from Echis carinatus venom: Characterization and cross-reactions. J Biol Chem 2002;277(19):17072-8.

43. Kurnal NA, Yalcin SC. Acaricidal, repellent and oviposition deterrent activities of Datura stramonium L. Against adult Tetranychus urticae (Koch). J Pestic Sci 2009;14:54-7.

44. Shirdel Z, Madani H, Mirbadalzadah R. Improvement of hyperglycemia in diabetic rats by ethanolic extract of red date leaves. Horm Signal 2011;31:1957-9.

45. Meiselman HL, Halpern BP, George P. Dateo. USA: Food Sci Lab, US Army Center; 1975. p. 76-7. 
46. Medicinal Herbs Ziziphus jujube. Available from: http://www. herbsnatural.com.

47. Courtsey of USDA Forest Service. Plant Profile for Zizyphus (common jujube".net.

48. Ziping X, Weihua F, Jiakang C, Weibo J. Antioxidant activity and total phenolic contents in peel and pulp of Chinese jujube (Ziziphus jujuba mill) fruits. J Food Biochem 2009;33:613-29.

49. Sawarkar DJ, Vijaya C, Turaskar AO, Shende VS, Sawant VA, Borkar SN. Hepatoprotective activity of ethanolic and ethyl acetate extract of Ziziphus mauriatiana on liver damaged caused by paracetamol in rats. Res J Pharmacogn Photochem 2009;1:194-7.

50. Kumar SP, Basheeruddin AN, Kumar MP, Khajuria D. Protective effect of Zizyphus jujuba fruit extract against paracetamol and thioacetamide induced hepatic damage in rats. Internet J Pharmacol 2008;7.

51. Fatemeh V, Mohsen FN, Kazem B. Vaccine and Serum Research Institute. Mashhad, Iran: Pharmacorp Publishers; 2008.

52. CSIR. The Wealth of India. First Supplement Series (Raw Materials). Second Print. Vol. 5. New Delhi: R-Z, National Institute of Science Communication and Information Resources, CSIR; 2004. p. 421.

53. Kuliev AA, Guseinova NK. The content of vitamin C, B1, B2 and E in some fruits. Referativnyi Zhurnel 1974;2:69-73.

54. Tomoda M, Shimuju N, Gonda R. Pectic substances II. The location of O-acetyl groups and the smith degradation of Ziziphus pectin A. Chem Pharm Bull 1985;33(9):4017-20.

55. Majumdar GP. Vedic Plants in BC. Law Commemoration; 1945. p. 1.

56. Kirtikar R, Nadkarni KM, Basu BD. Indian medicinal plants. Indian Mater Med 2010;2:1315-9.

57. Singh M, Jindal SK, Kavia ZD, Jangid BL. Khem Chand. Traditional Methods of Cultivation and Processing of Henna. Henna, Cultivation, Improvement and Trade. Jodhpur, India: Central Arid Zone Research; 2008. p. 14-21.

58. Harborne SB, Baxter A. A Handbook of Bioactive Compounds from Plants. London, Philadelphia; Tylor and Francis; 1995.

59. Blanks T, Brown S, Cosgrave B, Woody J, Bentley VO, Sullivan N. The Body Shop Book of Wellbeing Mind, Body, and Soul. London: Ebury Press; 1998. p. 173-92.

60. Natarajan V, Venugopal PV, Menon T. Effect of Azadirachta indica (neem) on the growth pattern of dermatophytes. Indian J Med Microbiol 2003;21:98-101.

61. Hemem SS, Brus LE. Activity of some plant extracts against common pathogens in bacterial skin infection. J Chem Phys Sci 2010;80:4403-9.

62. Henglein A, Janata ME, Ershov BG. Absorption spectrum and chemical reactions of colloidal cadmium in aqueous solution. J Phys Chem Sci 1992;96(11):4598-602

63. Butenko A, Chubakov P, Danilova Y, Phys Z, Atoms D. Nonlinear optics of metal fractal clusters. Mol Clust 1990;17:283-9.

64. Gutierrez M, Henglein A. Sonochemistry and sonoluminescence: Effects of external pressure. J Phys Chem Sci 1993;97:158-62.

65. Pillai Z, Alivisatas AP, Kamat P. What factors control the size and shape of silver nanoparticles in the citrate ion reduction method? J Phys Chem Sci 2004;108:945.

66. Geoffrey JA, Hamilton R, Hermann LR. Molecular rectification: Asymmetric current-voltage curves from self-assembled monolayers of a donor-( $\pi$-bridge)-acceptor dye. J Mater Chem 2003;13:1501-3.

67. Satheesh K. Biological synthesis of silver nanoparticles (Ag-NPS) by Lawsonia inermis (Henna) plant aqueous extract and its antimicrobial activity against human pathogens. Int J Curr Microbiol Appl Sci 2016;5:926-37.

68. Pumand D, Sleytr UB. The application of bacterial S-layersinmolecular nanotechnology. Nanotechnology 1999;17:8-12

69. Gardea-Torresday J, Jose-Yacaman M. Multiple twinned gold nanorods grown by bio- reduction techniques. J Nanopart Res 2001;3:475-81.

70. Chandran SP, Chaudhary M, Pasricha R, Ahmad A, Sastry M. Synthesis of gold nanotriangles and silver nanoparticles using Aloe vera plant extract. Biotechnol Prog 2006;22(2):577-83.

71. Arulkumar S, Sabesan M. Rapid preparation process of antiparkinsonian drug Mucuna pruriens silver nanoparticle by bioreduction and their characterization. Pharmacogn Res 2010;2:233-6.

72. Kathireswari P, Gomathi S, Saminathan K. Green synthesis of silver nanoparticles using Vitex negundo and its antimicrobial activity against human pathogens. Int J Curr Microbiol Appl Sci 2014;3(8):614-21.

73. Singhal G. Zizyphus mauritiana extract-mediated green, rapid synthesis of gold nanoparticles and its antibacterial activity. J Nanostruct Chem 2015;5:265-73.

74. Ono M, Ito Y, Nohara T. Four new halimane-type diterpenes, vitetrifolins D-G, from the fruit of Vitex trifolia. Chem Pharm Bull (Tokyo) 2001;49:1220-2
75. Assunta H. Vitex agnus castus chaste tree berry/Monk's pepper: What's in a name? Aust Cent Complement Med 2006;25:888

76. Bornhorst HL. Growing Native Hawaiian Plants: A How-to Guide for the Gardener. Honolulu: The Bess Press; 1996. p. 26-7.

77. Edward FG. Vitex trifolia 'Variegata' - Variegated Vitex. Fact Sheet FPS-611; 1999. p. 1-3.

78. Watson LE, Bates PL, Evans TM, Unwin MM, Estes JR. Molecular phylogeny of subtribe Artemisiinae (Asteraceae), including Artemisia and its allied and segregate genera. BMC Evol Biol 2002;2:17.

79. Durán N, Marcato PD, Alves OL, Souza GI, Esposito E. Mechanistic aspects of biosynthesis of silver nanoparticles by several Fusarium oxysporum strains. J Nanobiotechnol 2005;3:8.

80. Xie J, Lee JY, Wang DI, Ting YP. Identification of active biomolecules in the high-yield synthesis of single-crystalline gold nanoplates in algal solutions. Small 2007;3(4):672-82.

81. Zhou Y, Chen W, Itoh H, Naka K, Ni Q, Yamane H, et al. Preparation of a novel core-shell nanostructured gold colloid-silk fibroin bioconjugate by the protein in situ redox technique at room temperature. Chem Commun (Camb) 2001;(23):2518-9.

82. Scott L, Cadman A, McMillan I. Early history of Cainozoic Asteraceae along the Southern African West Coast. Rev Palaeobot Palynol 2006; 142:47-52.

83. Watson LE, Bates PL. Molecular phylogeny of sub tribe Artemisiinae (Asteraceae), including Artemisia and its allied and segregate genera. BMC Evol Biol 2002;171:471.

84. White NJ.Assessment of the pharmacodynamic properties of antimalarial drugs in vivo. Antimicrob Agents Chemother 1997;41(7):1413-22.

85. Van Wyk BE, Van Oudtshoorn B, Gericke N. Medicinal Plants of South Africa. Pretoria: Briza Publication; 1997. p. 304.

86. Mukinda JT. Acute and chronic toxicity of the flavonoids-containing plant, Artemisia afra in rodents. Western Cape, South Africa: University of the Western Cape; 2005

87. Jakupovic J, Kuhnke J, Schuster A, Metwally MA, Bohlmann F. Glaucolids and guaianolids from Artemisia afera. Phytochemistry 2004;271:129.

88. Watt JM, Breyer-Brandwijk MG. The Medicinal and Poisonous Plants of Southern and Eastern Africa. University Microfilms International $2^{\text {nd }}$ edition. London: Livingstone; 1986.

89. Sastry VG, Kumar KP. Toxicity studies of ethanolic extract of spondiaspinnata Kurz in experimental animals. Int J Mech Eng Comput Appl 2013;1(1):17.

90. Pimm SL, Joppa LN. How many plant species are there, what are they, and at what rate are they going to extinct? Ann Mo Bot Gard 2015;100:170-1090

91. Azam-Ali SP, Bonkoungou E, Bowe C, Kock D, Godara A, Williams JT. Ber. International Centre for Underutilised Crops. Southampton, UK. Scopemed J 2006;:1-20.

92. Marg KS. The Wealth of India Raw Material. Vol. X-Z. New Delhi: Council of Industrial and Scientific Research; 1989. p. 111-24

93. Awasthi OP, More TA. Genetic diversity and status of Ziziphus in India. J Acta Hortic 2009;840:33-40.

94. Pareek OP. Fruits for the Future 2: Ber. Southampton, UK: International Centre for Underutilised Crops, University of Southampton; 2001. p. 1-32.

95. Duke JA. Handbook of Legumes of World Economic Importance. New York, USA: Plenum Press; 1981.

96. Gliessman SR, Garcia R, Amador M. The ecological basis for the application of traditional agricultural technology in the management of tropical agro-ecosystems. J Agro Ecosyst 1981;7:173-85.

97. Bravo L, Siddhuraju P, Saura-Calixto F. Effect of various processing methods on the in vitro starch digestibility and resistant starch content of Indian pulses. J Agric Food Chem 1998;46:4667-74.

98. Bailey LH, Bailey ZE. Hortus Third: A Concise Dictionary of Plants Cultivated in the United States and Canada. New York, NY, USA: Macmillan; 1976.

99. Beta T, Nam S, Dexter JE, Sapirstein HD. Phenolic content and antioxidant activity of pearled wheat and roller-milled fractions. Cereal Chem J 2005;82:390-3

100. Agharkar S. Medicinal Plants of Bombay Presidency. Jodhpur, India: Scientific Publication; 1991. p. 1-2.

101. Amin KM, Khan MN, Rahman HS. Sexual function improving effect of Mucuna pruriens in sexually normal male rats. Fitoterapia $\mathbf{J}$ 1996;67(1):53-8.

102. Becker M, Johnson D. Nutrient cycling in agrosystems. Int Dev Res Cent 1998:6:1-11.

103. Bhaskar A, Vidhya VG. Hypoglycemic effect of Mucuna pruriens seed extract on normal and streptozotocin-diabetic rats. Fitoterapia J 
2008;79(7-8):539-43

104. Biswas TK, Maity LN, Mukherjee B. Wound healing potential of Pterocarpus santalinus: A pharmacological evaluation. Int J Low Extrem Wounds Fitoterapia 2004;79(7-8):539-43.

105. Buckles D. Velvet bean: A 'new' plant with a history. Econ Bot 1995;49(1):13-25.

106. Caius JF. The Medicinal and Poisonous Legumes of India. Jodhpur, India: Scientific Publication: 1989. p. 70-1.
107. Chadha KL. Advances in Horticulture - Medicinal and Aromatic Plants. New Delhi: Malhotra Publishing House; 1995. p. 522-4.

108. Chamakura RP. Bufotenine - A hallucinogen in ancient snuff powders of South America and a drug of abuse on the streets of New York city. Forensic Sci Rev 1994;6(1):1-18.

109. Chattopadhyay S, Datta SK, Mahato SB, Production of L DOPA from cell suspension culture of Mucuna pruriens f. pruriens. J Plant Cell Rep 1994;13(9):519-22. 